\section{The Timing of Rapid Infant Weight Gain in Relation to Childhood Obesity}

\author{
Young-Lim Shin* \\ Department of Pediatrics, Soonchunhyang University Bucheon Hospital, Soonchunhyang University College \\ of Medicine, Bucheon, Korea
}

\author{
Received October 11, 2019 \\ Reviewed November 2, 2019 \\ Accepted November 14, 2019 \\ ${ }^{*}$ Corresponding author \\ Young-Lim Shin \\ https://orcid.org/0000-0002-4327-4517 \\ Department of Pediatrics, \\ Soonchunhyang University Bucheon \\ Hospital, Soonchunhyang University \\ College of Medicine, 170 Jomaru-ro, \\ Wonmi-gu, Bucheon 14584, Korea \\ Tel: +82-32-621-5407 \\ Fax: +82-32-621-5016 \\ E-mail:ylshin@schmc.ac.kr
}

Over the last 4 decades, the prevalence of obesity in children and adolescents has increased 10-fold worldwide. ${ }^{1}$ Excessive weight gain occurring in early childhood leads to a greater degree of obesity in adolescence and adulthood. ${ }^{2,3} \mathrm{~A}$ large number of studies on obesity in childhood and adolescence have been conducted, as it is a significant public health concern for obesity-related cardiovascular and metabolic disease morbidity and mortality,

Numerous studies have reported postnatal factors associated with childhood and adolescent obesity, such as low birth weight, high-protein formula feeding, and rapid weight gain in infancy, ${ }^{5-7}$ and several investigators have shown interest in the association between rapid weight gain in the first 2 years of life and increased subsequent risk of obesity., ${ }^{8,9}$ Rapid infant weight gain is defined as an increase of $>0.67$ in weight-for-age Z-scores between two time points during the first 2 years of life. ${ }^{8}$ The proportion of rapid weight gain in infancy varied from $10 \%$ to $50 \%,{ }^{9}$ and it is associated with a higher risk of obesity in childhood. ${ }^{8,9}$ The exact mechanism of rapid infant weight gain remains uncertain. Some researchers proposed that infants with rapid weight gain have higher insulin resistance, central fat deposition, general fat accumulation, and microbiota. ${ }^{9-11}$ Risk factors related to rapid infant weight gain include low birth weight, ${ }^{12}$ formula feeding, ${ }^{12}$ and higher protein intake. ${ }^{6}$ Low birth weight has been related to excess adiposity, and formula feeding is considered a more important risk factor in rapid weight gain than breastfeeding. ${ }^{12}$

The studies assessing childhood adiposity used several measurement techniques including weight, height, body mass index (BMI), waist circumference, skinfold thickness, bioelectrical impedance, dual energy X-ray absorptiometry, magnetic resonance imaging (MRI), computed tomography, and ultrasound. Although BMI has a high correlation with adiposity, it has limitations in measuring total body adiposity and distinguishing between fat and muscle. MRI is considered the gold standard for measuring adiposity and differentiation of body fat depots, and it is suitable for children due to the lack of radiation exposure. ${ }^{13} \mathrm{~A}$ population-based prospective cohort study by Vogelezang et al. ${ }^{14}$ investigated the associations of fetal and infant weight change with visceral fat index, pericardial fat index, and liver fat fraction as measured by MRI. This study is particularly relevant since visceral and organ fat are related to an increased incidence of cardiometabolic disease.

The exact period of rapid weight gain during infancy that is predictive of obesity in adolescence and adulthood is unclear. Ong and 
$\operatorname{Loos}^{15}$ reported that rapid weight gain from birth to 2 years was associated with a 2 - to 3 -fold increased risk of obesity later in childhood and adulthood, and the period of rapid weight gain and age at outcome assessment largely influenced this relationship. FeldmanWinter et al. ${ }^{16}$ found that infant weight gain in the first week of life is significantly related to overweight at the age of 2 , regardless of birth weight. Another study suggested that rapid weight gain during the first week of life is a determinant for the development of obesity. ${ }^{10}$ A systematic review determined that rapid growth during the first years of life is associated with obesity during the course of life. ${ }^{8}$ Intervention strategies in preventing increased weight gain during the first year of life were more effective than the second year of life. ${ }^{17}$ A study examined the relationships between breast and formula feeding trajectories among birth weight and weight at 7-12 months of age, and a lower percentage of breastfeeding in high birth weight infants showed higher weight at 7-12 months of age, suggesting an initial target for obesity-prevention programs during the first 6 months of life. ${ }^{18}$ Larqué et al. ${ }^{7}$ advised that increases in body weight $\mathrm{Z}$-score $>0.67$ standard deviation should be avoided from birth to 6 months. More significant intervention effects were reported with weight gain during 0-6 and 0-12 months, but not between 0 and 24 months. ${ }^{14,19}$ The study by Vogelezang et al. ${ }^{14}$ suggested that both fetal and infant growth influence childhood adiposity and emphasized the need to implement strategies to prevent obesity later for infants with fetal growth deceleration followed by postnatal growth acceleration. However, it could be biased since they analyzed weight change together over the periods 0-6 months, 0-11 months, and 0-24 months, and further investigation is required to identify the exact timing of rapid infant weight gain related to childhood obesity.

In conclusion, knowledge of the specific critical periods in infancy leading to obesity may help determine effective preventive strategies. Further studies are needed to elucidate infant growth patterns, as prevention of rapid infant weight gain could help reduce the risk of adult obesity.

\section{CONFLICTS OF INTEREST}

The author declares no conflict of interest.

\section{REFERENCES}

1. NCD Risk Factor Collaboration (NCD-RisC). Worldwide trends in body-mass index, underweight, overweight, and obesity from 1975 to 2016: a pooled analysis of 2416 populationbased measurement studies in 128.9 million children, adolescents, and adults. Lancet 2017;390:2627-42.

2. Geserick M, Vogel M, Gausche R, Lipek T, Spielau U, Keller E, et al. Acceleration of BMI in early childhood and risk of sustained obesity. N Engl J Med 2018;379:1303-12.

3. Baird J, Fisher D, Lucas P, Kleijnen J, Roberts H, Law C. Being big or growing fast: systematic review of size and growth in infancy and later obesity. BMJ 2005;331:929.

4. Singh AS, Mulder C, Twisk JW, van Mechelen W, Chinapaw MJ. Tracking of childhood overweight into adulthood: a systematic review of the literature. Obes Rev 2008;9:474-88.

5. Labayen I, Ruiz JR, Vicente-Rodríguez G, Turck D, Rodríguez G, Meirhaeghe A, et al. Early life programming of abdominal adiposity in adolescents: The HELENA Study. Diabetes Care 2009;32:2120-2.

6. Weber M, Grote V, Closa-Monasterolo R, Escribano J, Langhendries JP, Dain E, et al. Lower protein content in infant formula reduces BMI and obesity risk at school age: follow-up of a randomized trial. Am J Clin Nutr 2014;99:1041-51.

7. Larqué E, Labayen I, Flodmark CE, Lissau I, Czernin S, Moreno LA, et al. From conception to infancy: early risk factors for childhood obesity. Nat Rev Endocrinol 2019;15:456-78.

8. Monteiro PO, Victora CG. Rapid growth in infancy and childhood and obesity in later life: a systematic review. Obes Rev 2005;6:143-54.

9. Zheng M, Lamb KE, Grimes C, Laws R, Bolton K, Ong KK, et al. Rapid weight gain during infancy and subsequent adiposity: a systematic review and meta-analysis of evidence. Obes Rev 2018;19:321-32.

10. Stettler N, Stallings VA, Troxel AB, Zhao J, Schinnar R, Nelson SE, et al. Weight gain in the first week of life and overweight in adulthood: a cohort study of European American subjects fed infant formula. Circulation 2005;111:1897-903.

11. Craig SJ, Blankenberg D, Parodi AC, Paul IM, Birch LL, Savage JS, et al. Child weight gain trajectories linked to oral mi- 
crobiota composition. Sci Rep 2018;8:14030.

12. Mihrshahi S, Battistutta D, Magarey A, Daniels LA. Determinants of rapid weight gain during infancy: baseline results from the NOURISH randomized controlled trial. BMC Pediatr 2011; 11:99.

13. Horan M, Gibney E, Molloy E, McAuliffe F. Methodologies to assess paediatric adiposity. Ir J Med Sci 2015;184:53-68.

14. Vogelezang S, Santos S, Toemen L, Oei EH, Felix JF, Jaddoe VW. Associations of fetal and infant weight change with general, visceral, and organ adiposity at school age. JAMA Netw Open 2019;2:e192843.

15. Ong KK, Loos RJ. Rapid infancy weight gain and subsequent obesity: systematic reviews and hopeful suggestions. Acta Paediatr 2006;95:904-8.

16. Feldman-Winter L, Burnham L, Grossman X, Matlak S, Chen
N, Merewood A. Weight gain in the first week of life predicts overweight at 2 years: a prospective cohort study. Matern Child Nutr 2018;14:e12472.

17. Rotevatn TA, Melendez-Torres GJ, Overgaard C, Peven K, Hyldgaard Nilsen J, Bøggild H, et al. Understanding rapid infant weight gain prevention: a systematic review of quantitative and qualitative evidence. Eur J Public Health 2019 Aug 13 [Epub]. https://doi.org/10.1093/eurpub/ckz140

18. Goetz AR, Mara CA, Stark LJ. Greater breastfeeding in early infancy is associated with slower weight gain among high birth weight infants. J Pediatr 2018;201:27-33.

19. Koletzko B, von Kries R, Closa R, Escribano J, Scaglioni S, Giovannini M, et al. Lower protein in infant formula is associated with lower weight up to age $2 \mathrm{y}$ : a randomized clinical trial. Am J Clin Nutr 2009;89:1836-45. 